\title{
Diabetic hearts have lower basal urocortin levels that fail to increase after cardioplegic arrest: Association with increased apoptosis and postsurgical cardiac dysfunction
}

\author{
Carol Chen-Scarabelli, MSc, PhD, FAHA, ${ }^{a}$ Richard Knight, MD, PhD, ${ }^{b}$ Anastasis Stephanou, PhD, ${ }^{b}$ \\ Gabriele Scarabelli, MD ${ }^{\mathrm{c}}$ Francesco Onorati, MD, PhD, ${ }^{\mathrm{d}}$ Maddalena Tessari, MSc, PhD, ${ }^{\mathrm{d}}$ \\ Alessio Rungatscher, MD, ${ }^{\mathrm{d}}$ Jagat Narula, MD, PhD, FAHA, MACC, ${ }^{\mathrm{e}}$ Louis Saravolatz, MD, MACP, \\ Alessandro Mazzucco, MD, ${ }^{\mathrm{d}}$ Giuseppe Faggian, MD, ${ }^{\mathrm{d}}$ and Tiziano M. Scarabelli, MD, PhD, FAHA ${ }^{\mathrm{c}, \mathrm{e}}$
}

\begin{abstract}
Objectives: The present study investigated the cardioprotective role of urocortin (Ucn) and its relationship with protein kinase $\mathrm{C}$ (PKC) $\varepsilon$ and $\mathrm{PKC} \delta$ in patients with (DMPs) and without (NDMPs) diabetes mellitus after on-pump cardiac surgery (OPCS). The molecular mechanisms responsible for the reported worse outcomes of DMP after OPCS remain unknown.
\end{abstract}

\begin{abstract}
Methods: Two sequential biopsy specimens were obtained from the right atrium of 27 DMPs and 22 NDMPs before and after cardiopulmonary bypass.

Results: Postcardioplegic induction of Ucn in NDMPs $(P<.01)$ was not observed in the DMPs, whose precardioplegic Ucn levels were 50\% lower than those in the NDMPs $(P<.05)$. In the NDMPs, cardioplegic arrest increased PKC $\varepsilon$ mRNA and protein $(P<.05)$; overexpression of PKC $\delta$ was not seen. In contrast, DMPs showed increased PKC $\delta$ expression $(P<.01)$, with no change in PKC $\varepsilon$. Apoptosis was more than twofold greater in the postcardioplegic samples from the DMPs than in those from the NDMPs. The apoptotic myocytes were Ucn negative and exhibited nuclear relocation of $\mathrm{PKC} \delta$. Enhanced PKC $\varepsilon /$ mitochondrial co-localization was observed in viable, Ucn-positive, myocytes. The leakage of troponin I documented in the DMPs was greater than that in the NDMPs, although the difference was not statistically significant $(P=.06)$. Furthermore, despite a similar incidence of perioperative acute myocardial infarction, the DMPs did not show postoperative improvement of systolic or diastolic function, although that was seen in the NDMPs $(P<.05)$.
\end{abstract}

Conclusions: Cardioplegic arrest failed to induce in DMPs myocyte overexpression of Ucn or PKCe but was associated with induction and mitochondrial relocation of $\mathrm{PKC} \delta$, resulting in apoptosis. Failure to overexpress Ucn in the DMPs was associated with apoptosis and cardiac dysfunction and, thus, might contribute to worse postoperative outcomes. (J Thorac Cardiovasc Surg 2014;148:2296-308)

See related commentary on page 2309 .

Diabetes mellitus (DM) is a well-established risk factor for the morbidity and mortality associated with on-pump cardiac surgery (OPCS). ${ }^{1}$ Although patients with DM

From the Veterans Affairs Ann Arbor Health Care System, ${ }^{\mathrm{a}}$ University of Michigan, Ann Arbor, Mich; Medical and Molecular Biology Unit, ${ }^{\mathrm{b}}$ University College London, London, United Kingdom; Center for Heart and Vessel Preclinical Studies, ${ }^{\mathrm{c}}$ St John Hospital and Medical Center, Wayne State University, Detroit, Mich; Division of Cardiothoracic Surgery, ${ }^{\mathrm{d}}$ University of Verona, Verona, Italy; Zena and Michael A. Wiener Cardiovascular Institute, ${ }^{\mathrm{e}}$ Icahn School of Medicine at Mount Sinai, New York, NY.

Disclosures: Authors have nothing to disclose with regard to commercial support.

Received for publication Dec 16, 2013; revisions received May 5, 2014; accepted for publication May 9, 2014; available ahead of print June 20, 2014

Address for reprints: Tiziano M. Scarabelli, MD, PhD, FAHA, Center for Heart and Vessel Preclinical Studies, St John Hospital and Medical Center, Wayne State University School of Medicine, 22201 Moross Rd, Professional Building II, Suite 350, Detroit, MI 48236 (E-mail: tiziano.scarabelli@stjohn.org).

$0022-5223 / \$ 36.00$

Copyright (c) 2014 by The American Association for Thoracic Surgery

http://dx.doi.org/10.1016/j.jtcvs.2014.05.018
(DMPs) account for $28 \%$ of all those undergoing coronary artery bypass grafting $(\mathrm{CABG}),{ }^{1}$ such patients constitute a larger percentage of the postoperative morbidity and mortality population, with a reported $50 \%$ to $90 \%$ increase in mortality among DMPs. ${ }^{1-5}$ Cardiac pathologic entities such as myocardial infarction, followed by stroke, were the most common cause of late mortality after CABG in DMPs. ${ }^{2}$ Compared with non-DMPs (NDMPs), the postoperative morbidity has also been greater among DMPs, ${ }^{1,6-8}$ with greater rates of reoperation infection, ${ }^{1-7}$ a greater incidence of peri- and postoperative neurologic complications, ${ }^{6-8}$ and longer hospitalization periods. ${ }^{1,7}$ It has also been reported that cardiopulmonary bypass (CPB) induces greater oxidative stress in DMPs than in NDMPs, with quantitatively and qualitatively different CPB-induced and cardioplegia-induced gene expression that is potentially responsible for the different inflammatory reactions in these 2 patient groups. ${ }^{9}$ Additionally, both early ${ }^{1,6-8}$ and late $\mathrm{e}^{1,3-8,10,11}$ mortality were greater in DMPs.

Apoptotic cell death has been implicated in the pathogenesis of the iatrogenic ischemia-reperfusion (I/R) injury 


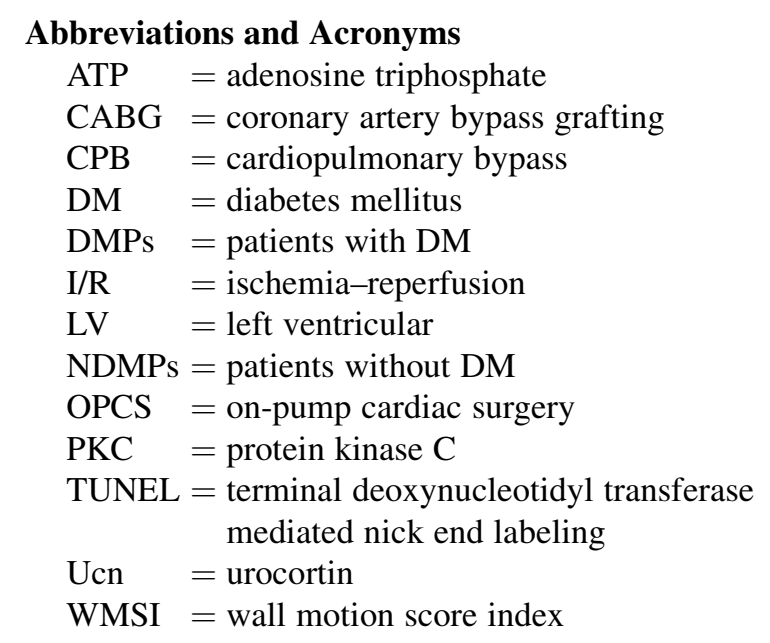

associated with OPCS. DNA fragmentation has been detected using terminal deoxynucleotidyl transferase mediated nick end labeling (TUNEL) staining in myocardial biopsy specimens from patients undergoing OPCS, with apoptotic rates of $0.03 \%$ and $3 \%$ to $6 \%$ in ventricular and atrial samples, respectively. ${ }^{12,13} \mathrm{DM}$ was also associated with an increased occurrence of apoptotic cell death, although the underlying molecular mechanisms are poorly understood. ${ }^{14}$

Urocortin (Ucn) is a 40-amino acid member of the corticotrophin-releasing factor family ${ }^{15}$ endogenously expressed in the human heart. ${ }^{16}$ The coexpression of Ucn and its cognate receptor in cardiac myocytes suggests that endogenous Ucn might exert autocrine and/or paracrine effects on the normal and diseased human heart. Biologically active Ucn, for instance, is released from isolated myocytes exposed to simulated ischemia and confers cardioprotective properties on the culture medium that are abrogated by corticotropin-releasing factor receptor antagonists. ${ }^{17}$ In addition, plasma Ucn is increased in the circulation of patients experiencing acute myocardial infarction. ${ }^{18}$

We have previously reported that warm blood cardioplegia in NDMPs is associated with increased endogenous myocyte expression of Ucn and that Ucn-positive myocytes are viable but that Ucn-negative cells show evidence of apoptosis. ${ }^{13}$ Furthermore, enhanced mitochondrial translocation of protein kinase $\mathrm{C}$ (PKC) $\varepsilon$ (an established mechanism of Ucn-mediated cardioprotection ${ }^{19}$ ), has been previously observed in viable Ucn-positive myocytes after cardioplegic arrest. ${ }^{20}$ In contrast to the cardioprotective properties of $\mathrm{PKC} \varepsilon$, however, $\mathrm{PKC} \delta$ expression has been implicated in apoptosis in a variety of cellular systems, including the heart. ${ }^{21}$ Also, hyperglycemia has been shown to increase both $\mathrm{PKC} \delta$ activation and apoptosis in rat ventricular myocytes in vitro. ${ }^{22}$
Accordingly, in the present study, we have compared the induction of Ucn and the activation and translocation of $\mathrm{PKC} \varepsilon$ and $\mathrm{PKC} \delta$ in DMPs and NDMPs undergoing OPCS.

\section{METHODS \\ Patient Population}

The present study strictly conformed to the principles outlined in the Declaration of Helsinki. The institutional review board of the University of Verona approved the study, and all patients selected gave informed consent before enrollment. A total of 49 patients (27 DMPs and 22 NDMPs), who were admitted for elective on-pump CABG, were recruited (Table 1). All the patients had multiple-vessel coronary disease with class II-III symptoms, according to the Canadian Cardiovascular Society Angina Classification. To avoid potential preoperative bias affecting the circulating Ucn level and the corresponding Ucn-induced intracellular pathways, only patients with stable angina, a left ventricular ejection (LV) fraction $>40 \%$, and no significant organ comorbidities, who had been scheduled for isolated primary CABG, were enrolled in the present study (Table 2).

\section{Surgical Procedure}

The anesthesia regimen was standardized and consisted of intravenous propofol $(2 \mathrm{mg} / \mathrm{kg})$ and fentanyl $(0.010 \mathrm{mg} / \mathrm{kg})$ administration, followed by propofol infusion (150-200 $\mu \mathrm{g} / \mathrm{kg} / \mathrm{min})$ and isoflurane $(0.8 \%$ inspired concentration). Neuromuscular blockade was achieved using $4 \mathrm{mg} / \mathrm{h}$ vecuronium bromide. After median sternotomy and heparin $(3 \mathrm{mg} / \mathrm{kg})$ administration, the aorta, right atrium, and inferior vena cava were cannulated. The left internal mammary artery was harvested as a pedicle and was always anastomosed to the left anterior descending artery. The internal saphenous vein was always harvested from the best side, which was detected using preoperative clinical evaluation and Doppler scanning. The management of CPB was standardized and achieved, as previously described. ${ }^{23}$ Likewise, cardiac arrest and myocardial protection were standardized and achieved, as previously described. ${ }^{23}$ In brief, after aortic crossclamping, cardiac arrest was induced by cold blood cardioplegia at $4^{\circ} \mathrm{C}$, injected antegrade for about 3 minutes into the aortic root and then retrograde for an additional 2 minutes into the coronary sinus. A second maintenance solution $\left(21 \mathrm{mEq} \mathrm{K}+/ 800 \mathrm{~mL}\right.$ ) at $4^{\circ} \mathrm{C}$ was administered retrograde every 20 minutes. After completion of the distal anastomosis and before aortic crossclamp removal, a third reperfusion dose of warm $\left(37^{\circ} \mathrm{C}\right)$ blood cardioplegia was administered. The aortic crossclamp was then removed and construction of the proximal anastomoses begun. Inotropic drugs were not used until specimen retrieval had been completed.

\section{Tissue Sampling and Preparation}

Two sequential biopsy specimens were obtained from a virgin site in the right atrium by 2 highly experienced cardiac surgeons (G.F., A.M.). The first biopsy was taken as a control sample before starting CPB but before cardioplegia, using a small purse string suture of polypropylene 4-0, stitched on the middle lateral wall of the right atrium, far from the right appendage and quite below the superior vena cava atrial junction. The second was obtained as near as possible to the site of the previous sample, about 10 minutes after release of the aortic crossclamp, using a new purse string suture of polypropylene 4-0, also stitched on the middle lateral right atrial wall.

No clinical complications related to the sampling procedure occurred. Immediately after collection, each atrial biopsy specimen was cut into 2 parts, as previously described,$^{20}$ and used for immunofluorescent staining, RNA isolation, and protein isolation, respectively.

\section{RNA Isolation and Quantitative Polymerase Chain Reaction}

Total RNA was isolated from cardiac samples using an RNA isolator solution, TRIZol (Gibco-BRL, Sussex, United Kingdom), treated with 
TABLE 1. Operative details, clinical characteristics, and outcome data

\begin{tabular}{|c|c|c|c|}
\hline Variable & $\begin{array}{c}\text { DMPs } \\
(\mathbf{n}=\mathbf{2 7})\end{array}$ & $\begin{array}{l}\text { NDMPs } \\
(\mathrm{n}=\mathbf{2 2}) \\
\end{array}$ & $P$ valu \\
\hline Age (y) & $63.6 \pm 5.0$ & $61.5 \pm 3.0$ & .74 \\
\hline Gender & & & .540 \\
\hline Male & 14 & 12 & \\
\hline Female & 13 & 10 & \\
\hline HbA1c $(\%)$ & & & .001 \\
\hline Mean & 8.4 & 5.9 & \\
\hline Range & $8.4-8.8$ & $5.8-6.0$ & \\
\hline Glycemia at admission $(\mathrm{mg} / \mathrm{dL})$ & & & .001 \\
\hline Median & 163.6 & 105 & \\
\hline Range & $163.0-170.0$ & $98.0-105.0$ & \\
\hline Diabetes duration & & & - \\
\hline$>3 \mathrm{y}$ & 6 & NA & \\
\hline$>10 \mathrm{y}$ & 21 & NA & \\
\hline \multicolumn{4}{|l|}{ Medical management of DM } \\
\hline Oral agents & 5 & NA & \\
\hline Oral agents plus insulin & 14 & NA & \\
\hline Insulin & 8 & NA & \\
\hline Preoperative E & $78.2 \pm 8.7$ & $74.1 \pm 18.7$ & .3 \\
\hline Preoperative A & $81.0 \pm 15.2$ & $79.1 \pm 17.2$ & .683 \\
\hline Preoperative E/A & $0.9 \pm 0.2$ & $0.9 \pm 0.2$ & .399 \\
\hline Preoperative Ea & $8.6 \pm 1.7$ & $8.9 \pm 1.9$ & .504 \\
\hline Preoperative E/Ea & $9.5 \pm 2.3$ & $8.8 \pm 3.5$ & .424 \\
\hline Preoperative WMSI & $1.36 \pm 0.36$ & $1.35 \pm 0.43$ & .914 \\
\hline Preoperative LVEF & $52.8 \pm 4.2$ & $51.2 \pm 2.1$ & .106 \\
\hline CABG (n) & $3.6 \pm 0.6$ & $3.8 \pm 0.4$ & .97 \\
\hline \multicolumn{4}{|l|}{ Aortic crossclamp time (min) } \\
\hline Median & 48.2 & 49.2 & .755 \\
\hline Range & $42.0-56.0$ & $49.0-51.0$ & \\
\hline Preoperative troponin $\mathrm{I}(\mu \mathrm{g} / \mathrm{L})$ & $0.06 \pm 0.10$ & $0.07 \pm 0.09$ & .681 \\
\hline Perioperative AMI & $1 / 27(3.7)$ & $0 / 22(0)$ & .551 \\
\hline Perioperative pneumonia & $1 / 27(3.7)$ & $1 / 22(4.5)$ & .702 \\
\hline Prolonged intubation & $2 / 27(7.4)$ & $1 / 22(4.5)$ & .578 \\
\hline Postoperative AKI & $1 / 27(3.7)$ & $0 / 22(0)$ & .551 \\
\hline Stroke & $0 / 27(0)$ & $0 / 22(0)$ & NA \\
\hline
\end{tabular}

Data presented as mean \pm standard deviation or $\mathrm{n}(\%)$, unless otherwise noted. $D M P s$, Patients with diabetes mellitus; $N D M P s$, patients without DM; $H b A l c$, hemoglobin Alc; $D M$, diabetes mellitus; $W M S I$, wall motion score index; $L V E F$, left ventricular ejection fraction; $C A B G$, coronary artery bypass grafting; $A M I$, acute myocardial infarction; $A K I$, acute kidney injury; $N A$, not applicable.

DNAse (Promega, Madison, Wis), and subsequently reversed transcribed with Superscript II reverse transcriptase (Gibco BRL, Life Technologies, Carlsbad, Calif) and oligodT (18-mer) primer. ${ }^{20}$ Real-time, 1-step polymerase chain reaction for specific mRNA was performed using the QuantiTect SYBR Green polymerase chain reaction kit (Qiagen, Hilden, Germany) and LightCycler 1.5 instrument (Roche Diagnostics, Indianapolis, Ind), according to the manufacturer's instructions. The following specific primers were used to quantitate, by polymerase chain reaction, the transcript levels of the genes of interest. The Ucn primer sequences were $5^{\prime}$-GCTTGCTGGTGAAAAGGACC- $3^{\prime}$ (sense) and $5^{\prime}$-CTTGCCCACCGAGTCGAAT- $3^{\prime}$ (antisense). The PKC $\varepsilon$ primer sequences were $5^{\prime}$-ACCAAGCAGAAGACCAACAG- $3^{\prime}$ (sense) and $5^{\prime}$ TTCCTATGACACCCCAGATG- $3^{\prime}$ (antisense). The PKC $\delta$ sequences were $5^{\prime}$-GGAAGAAGCAATGGTCCAAG- $3^{\prime}$ (sense) and antisense $5^{\prime}$ GTATTATGTGGGAGAAAATG-3' (antisense).
TABLE 2. Echocardiographic and biochemical results stratified by group

\begin{tabular}{lccc}
\hline Variable & Preoperative & Postoperative & $P$ value \\
\hline DMPs & & & \\
E & $78.2 \pm 8.7$ & $78.7 \pm 11.5$ & .881 \\
$\mathrm{~A}$ & $81.0 \pm 15.2$ & $71.1 \pm 12.6$ & .008 \\
$\mathrm{E} / \mathrm{A}$ & $0.9 \pm 0.2$ & $1.1 \pm 0.2$ & .017 \\
$\mathrm{Ea}$ & $8.6 \pm 1.7$ & $9.0 \pm 1.3$ & .73 \\
$\mathrm{E} / \mathrm{Ea}$ & $9.5 \pm 2.3$ & $8.8 \pm 1.8$ & .209 \\
WMSI & $1.36 \pm 0.36$ & $1.38 \pm 0.42$ & .756 \\
LVEF & $52.8 \pm 4.2$ & $55.4 \pm 7.5$ & .136 \\
NDMPs & & & \\
E & $74.1 \pm 18.7$ & $91.9 \pm 9.1$ & .002 \\
$\mathrm{~A}$ & $79.1 \pm 17.2$ & $68.3 \pm 12.6$ & .008 \\
E/A & $0.9 \pm 0.2$ & $1.4 \pm 0.3$ & .001 \\
Ea & $8.9 \pm 1.9$ & $10.5 \pm 1.7$ & .002 \\
E/Ea & $8.8 \pm 3.5$ & $8.8 \pm 1.6$ & .972 \\
WMSI & $1.35 \pm 0.43$ & $1.17 \pm 0.21$ & .49 \\
LVEF & $51.2 \pm 2.1$ & $58.6 \pm 7.2$ & .0001 \\
\hline
\end{tabular}

Troponin I levels preoperatively from peripheral blood, intraoperatively at reperfusion 10 minutes after aortic declamping and at 6,12 , and 48 hours postoperatively: for DMPs, $0.06 \pm 0.10,1.52 \pm 0.83,5.38 \pm 3.94,11.09 \pm 13.59$, and $14.57 \pm 20.76 \mu \mathrm{g} / \mathrm{L}\left(P^{\mathrm{a}}=.0001\right)$; for NDMPs, $0.07 \pm 0.09,1.05 \pm 0.72$, $3.09 \pm 1.28,4.04 \pm 4.82$, and $5.13 \pm 13.53 \mu \mathrm{g} / \mathrm{L}\left(P^{\mathrm{a}}=.001\right)$, respectively. $P^{\mathrm{b}}=.037 ; P^{\mathrm{c}}=.050 . D M P s$, Patients with diabetes mellitus; WMSI, wall motion score index; $L V E F$, left ventricular ejection fraction; NDMPs, patients without diabetes mellitus; $P^{\mathrm{a}}$, time $P$ value; $P^{\mathrm{b}}$, group $P$ value; $P^{\mathrm{c}}$, group $\times$ time $P$ value.

\section{Immunoblotting Material and Approach}

The types and sources of the antibody used for the immunoblotting procedure were as follows. The antibody against actin (matrix protein $\mathrm{p} 84$ [heat shock protein 60]) and total PKC $\varepsilon$ and $\mathrm{PCK} \delta$ were obtained from Santa Cruz Biotechnology (Santa Cruz, Calif). The anti-phospho-PKC $\varepsilon$ (Ser729) and anti-phospho-PKC $\delta$ (Ser665) rabbit polyclonal antibody were purchased from Upstate Biotechnology (Millipore Corp, Lake Placid, NY). All secondary antibodies were conjugated to horseradish peroxidase, and the ensuing immunoreactive bands were developed using a Western lightning chemiluminescence kit (PerkinElmer Life Science, Waltham, Mass).

\section{Western Blotting}

The pre- and postcardioplegic cardiac specimens were homogenized in lysis buffer $(100 \mathrm{mmol} / \mathrm{L} \mathrm{NaCl}, 0.1 \%$ Triton X-100, $50 \mathrm{mmol} / \mathrm{L}$ Tris; $\mathrm{pH} 8.3$ ), loaded on $8 \%$ sodium dodecyl sulfate-polyacrylamide gel, separated by gel electrophoresis, transferred onto a nitrocellulose membrane, and probed with relevant primary antibody. The assessment of Ucn protein (molecular weight, 4693.52 Daltons) was performed as previously described using a Tricine sodium dodecyl sulfate-polyacrylamide gel electrophoresis system. ${ }^{20,24}$

\section{Mitochondrial, Nuclear, and Cytoplasmic Protein Fractionation, Characterization, and Assessment}

The mitochondrial, nuclear, and cytosolic fractions were prepared using commercially available kits (mitochondria isolation kit for tissue, Pierce Protein Research Products, Thermo Fisher Scientific, Rockford, Ill; and nuclear extraction kit, Millipore, Billerica, Mass), according to the manufacturer's instructions. Equal amounts ( $20 \mu \mathrm{g}$ ) of nuclear, mitochondrial, and cytoplasmic proteins were separated using sodium dodecyl sulfate-polyacrylamide gel electrophoresis, as previously described, ${ }^{20}$ and were subsequently probed with antibody against total and phosphorylated PKC $\varepsilon$ and $\mathrm{PKC} \delta$. Anticytochrome oxidase subunit IV, anti-nuclear matrix protein $\mathrm{p} 84$, and antiactin antibody were used to probe for mitochondrial, nuclear, and cytoplasmic fractions, respectively. ${ }^{25}$ 

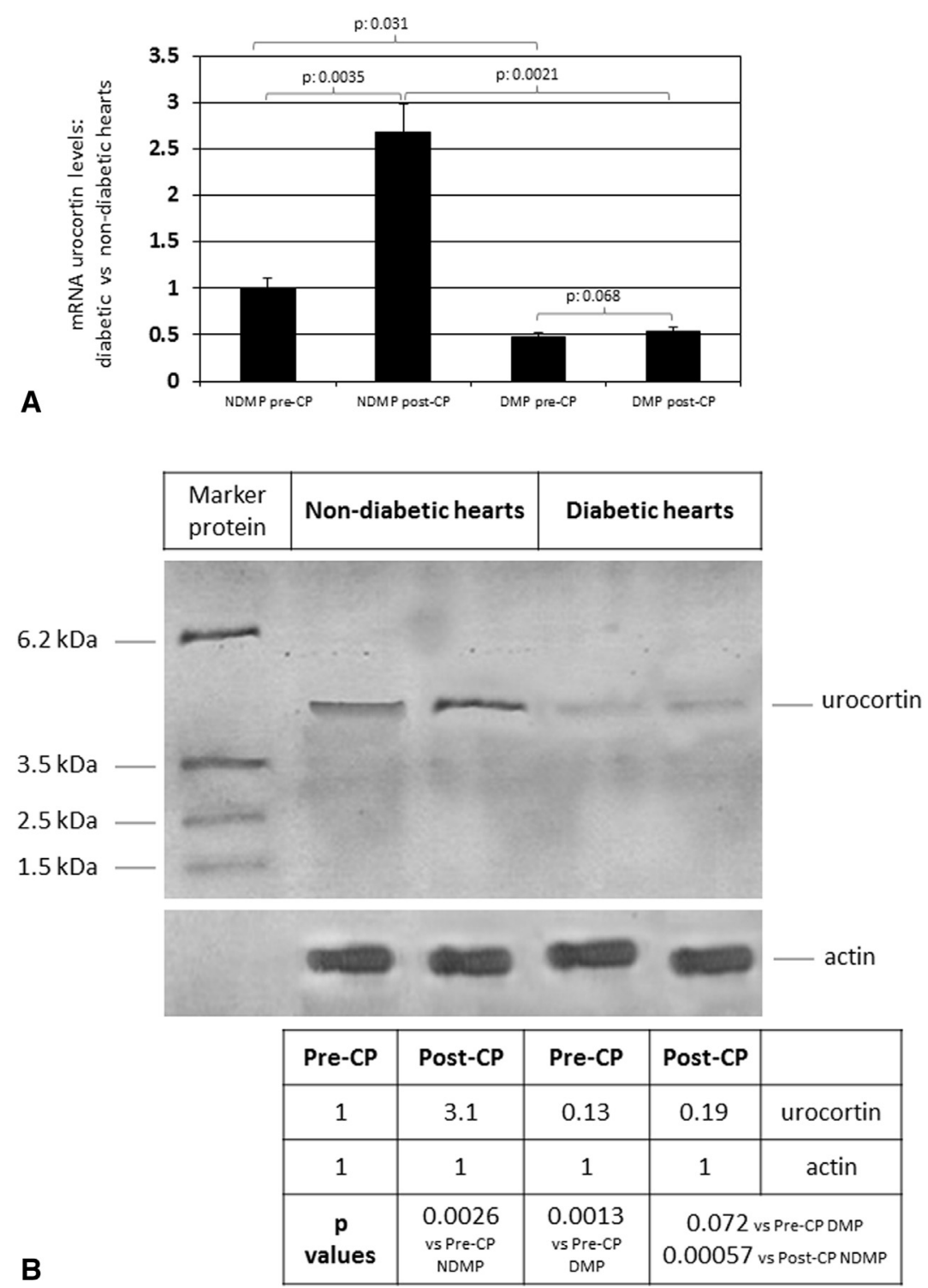

FIGURE 1. A, Quantitative polymerase chain reaction of urocortin messenger RNA (mRNA) levels in cardiac samples collected before and after cardioplegic $(C P)$ arrest from patients without diabetes mellitus $(N D M P s)$ and patients with diabetes mellitus $(D M P s)$. **P<.01 and $* P<.05$. B, Expression of the urocortin protein, as determined by Western blotting of extracts from pre- and post-CP atrial tissues. A total of 54 samples from DMPs ( 27 taken before cardioplegia and 27 after release of aortic crossclamping) and 44 samples from NDMPs ( 22 obtained before cardioplegia and 22 after release of aortic crossclamping) were processed. To obtain adequate amounts of protein and mRNA, the pre- and post-CP samples collected from 3 patients were combined and processed together, with the exception of 1 pre- and post-CP batch from NDMPs composed of 4 samples. The blot shown is representative of 3 different blots. Marker proteins with the indicated molecular masses were also used.

\section{Immunocytochemistry Assessment}

Adjacent 5- $\mu \mathrm{m}$ myocardial sections were stained with TUNEL reagents (using a rhodamine fluorochrome) and/or antibody against Ucn, phosphorylated PKC $\varepsilon$, and phosphorylated $\mathrm{PKC} \delta$. Anticytochrome oxidase subunit IV antibody was used to specifically label mitochondria. When indicated, the myocardial sections were counterstained with propidium iodide or TO-PRO-3 (Life Technologies), as previously described. ${ }^{13,20,25,26}$ After washing and incubation with suitable secondary antibodies (DakoCytomation, Glostrup, Denmark), the sections were analyzed by a confocal microscopist (T.M.S.), who was unaware of the origin and sequence of the specimens. The data are expressed as the mean \pm standard deviation of 12 to 15 high power fields.

\section{Clinical Data}

High-sensitivity troponin I was assayed preoperatively from peripheral blood, intraoperatively at reperfusion, 10 minutes after aortic declamping, and, from the peripheral blood, at 6, 12, and 48 hours postoperatively.

The LV ejection fraction was calculated using routine transthoracic echocardiography according to the Simpson method. The wall motion score index (WMSI) was calculated using the 16-segment model for 
A
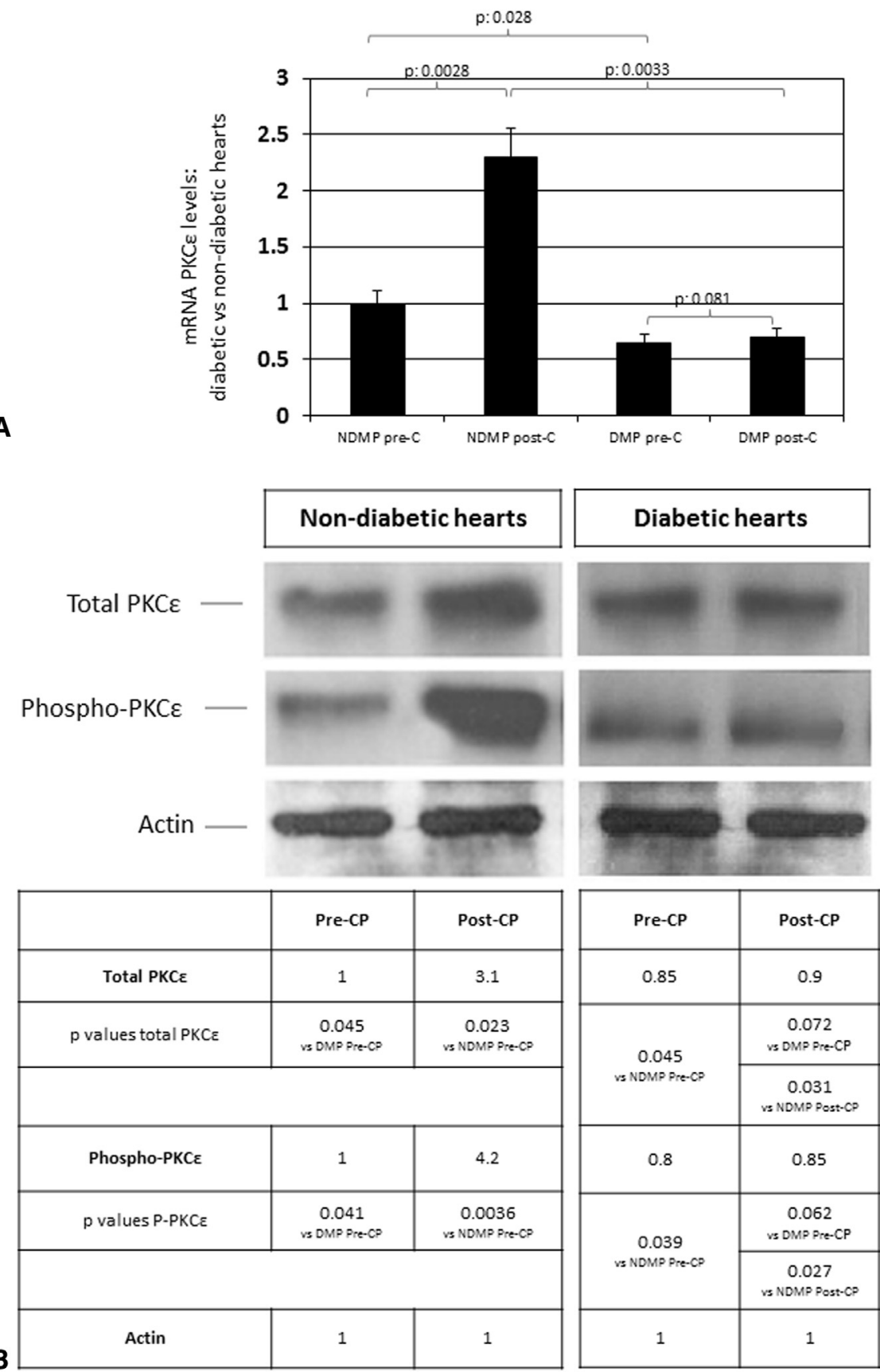

FIGURE 2. A, Quantitative polymerase chain reaction of protein kinase $\mathrm{C}(P K C) \varepsilon$ urocortin messenger RNA (mRNA) levels from pre- and postcardioplegic $(C P)$ myocardial samples from patients without $(N D M P s)$ and with $(D M P s)$ diabetes mellitus. $* * P<.01$ and $* P<.05$. B, Expression of total and phosphorylated PKC $\varepsilon$ protein, as determined by Western blotting of extracts from nondiabetic and diabetic human hearts before and after $\mathrm{CP}$ arrest. A total of 54 samples from DMPs (27 taken before cardioplegia and 27 after release of aortic crossclamping) and 44 samples from NDMPs (22 obtained before cardioplegia and 22 after release of aortic crossclamping) were processed. To obtain adequate amounts of proteins and mRNA, pre- and post-CP samples collected from 3 different patients were combined and processed together, with the exception of 1 pre- and post-CP batch from NDMPs composed of 4 samples. The data shown are representative of 3 different experiments.

LV segmentation, as recommended by the American Society for Echocardiography, ${ }^{27}$ before admission to the operating room and at 96 hours postoperatively. The LV myocardial velocities were also recorded at the mitral annulus using pulsed-wave tissue Doppler imaging to investigate perioperative diastolic function, at the same measurement points (before admission to the operating room and 96 hours postoperatively) used for WMSI. ${ }^{28}$

The other data collected included age, gender, hemoglobin A1c, and serum glycemia at admission; number of CABG procedures; aortic crossclamp time; percentage of patients with perioperative acute myocardial 
infarction; prolonged ( $>48$ hours) ventilation; and incidence of pneumonia, acute renal insufficiency, and stroke.

\section{Statistical Analysis}

For the molecular data, significance was evaluated using the 2-tailed $t$ test. For the baseline data and clinical characteristics, the continuous variables were first tested for normality using the Shapiro-Wilk test and then compared using the Student $t$ test or Mann Whitney $U$ test, accordingly. The categorical variables were compared using the Fisher exact test and ordinal variables using the Mann Whitney $U$ test.

Repeated measures analysis of variance with Bonferroni's correction for multiple measurements was used to compare serial data related to perioperative troponin I leakage. The reported $P$ values include " $P$ a" (time- $P$ ), assessing change over time of the measured variable; " $P$ " " (group- $P$ ), assessing the level of difference between groups; and " $P$ " " $($ group $\times$ time $P)$ assessing the group-time interaction. The paired samples $t$ test was used to investigate the perioperative changes of the echocardiographic data. Statistical analysis was performed using the Statistical Package for Social Sciences program for Windows, version 15.0 (SPSS, Inc, Chicago, Ill).

\section{RESULTS}

In line with our previous findings, the hearts from NDMPs exposed to cardioplegic arrest and subsequent reperfusion exhibited a significant induction of Ucn at both the mRNA ( $268 \%$ of basic levels; $P<.01)$ and the protein (threefold increase; $P<.0026$ ) level. In contrast, the hearts from the DMPs showed a significantly lower basal expression of Ucn at RNA ( $50 \%$ lower) and protein ( $85 \%$ lower) levels $(P<.05$ vs NDMP basal levels) that was not significantly increased by OPCS ( $P=$ NS; Figure 1$)$. In the hearts from DMPs, cardioplegic arrest was associated with increased transcription of PKC $\varepsilon$ mRNA (230\% of internal control; $P<.05)$ and a threefold increased expression of total PKC $\varepsilon$ protein $(P<.05)$, with a 4.2 -fold increase in phosphorylated $\mathrm{PKC} \varepsilon(P<.01)$. In contrast, in the hearts of the DMPs, the precardioplegic level of PKC $\varepsilon$ mRNA, which was approximately $30 \%$ lower than that of the hearts of the NDMPs, did not increase after cardioplegic arrest. Similarly, total PKC $\varepsilon$ protein was not augmented after cardioplegic arrest in the DMPs nor was any increase in PKCE phosphorylation detected (Figure 2).

In the hearts of the NDMPs, PKC $\delta$ was detectable at both the mRNA and the protein level; however, OPCS did not result in any increase in the levels of the transcript, total protein, or its phosphorylation. In contrast, as depicted in Figure 3, the DPMs' hearts showed a baseline expression of PKC $\delta$ that was significantly greater at the mRNA and protein levels than that in the NDMPs' control hearts and was further increased after cardioplegia (mRNA, $269 \%$ of basic level; protein, 2.4-fold increase; $P<.01$ ), along with enhanced PKC $\delta$ phosphorylation (Figure 3).

Apoptotic cell death, assessed by TUNEL staining, was more than twofold greater in the postcardioplegic samples from the DMPs $(6.5 \% \pm 1.8 \%)$ than that in the NDMPs $(2.9 \% \pm 0.7 \%$; Figure $4, A)$. Nuclear translocation of $\operatorname{PKC} \delta$ (2.4-fold increase) was only seen in the postcardioplegic samples from DMPs (Figure $4, B$, and Table 3) but not in the samples from the NDMPs (data not shown).

Cardiac cells showing cytosolic staining for Ucn never exhibited nuclear relocation of PKC $\delta$ or TUNEL-positive staining (Figure 5, A). Furthermore, co-localization of nuclear PKC $\delta$ and TUNEL positivity was consistently seen in Ucn-negative myocytes (Figure 5, $B$, and Table 4).

In contrast, mitochondrial relocation of $\mathrm{PKC} \varepsilon$ was only detected in postcardioplegic samples from the NDMPs. In line with our previous findings, ${ }^{18} \mathrm{PKC} \varepsilon /$ mitochondria co-localization was observed in viable myocytes showing positive staining for Ucn (Figure 5, $A-D$, and Table 4).

\section{Clinical Data}

The clinical baseline and operative data proved comparable between the 2 groups, with the exception of the baseline serum glycemic value and percentage of hemoglobin 1c, which were greater in the DMPs (Table 1). No differences were recorded in the baseline serum troponin I or in any of the preoperative echocardiographic systolic and diastolic indexes (Table 1). A similar clinical outcome was also evident in terms of the incidence of perioperative acute myocardial infarction, pneumonia, prolonged ventilation, and acute renal insufficiency (Table 1). No stroke events were seen during the study period.

However, when perioperative leakage of troponin I was considered, both groups demonstrated a time-dependent increase in postoperative troponin I, although the DMPs had, overall, significantly greater leakage than did the NDMPs (Table 2).

Furthermore, despite a similar incidence of perioperative acute myocardial infarction, the DMPs did not show any improvement in their systolic function (using both the WMSI and LV ejection fraction), which was significantly improved in the NDMPs (Table 2). Similarly, the echocardiographic indexes of diastolic function in the DMPs remained comparable (with the exception of the E/A ratio) between the preoperative and postoperative periods, but almost all had improved significantly in the NDMPs after surgery (Table 2).

\section{DISCUSSION}

The mechanisms by which DM heightens the morbidity and mortality associated with OPCS are poorly understood. However, blood glucose levels seem to play a role, because hyperglycemia was found to influence long-term survival after $\mathrm{CABG}^{2,29}$ and was an independent risk factor for mortality in patients undergoing cardiac surgery. ${ }^{30}$ Likewise, stricter perioperative glucose control was shown to reduce mortality in DMPs undergoing $\mathrm{CABG}^{31-33}$ 
A

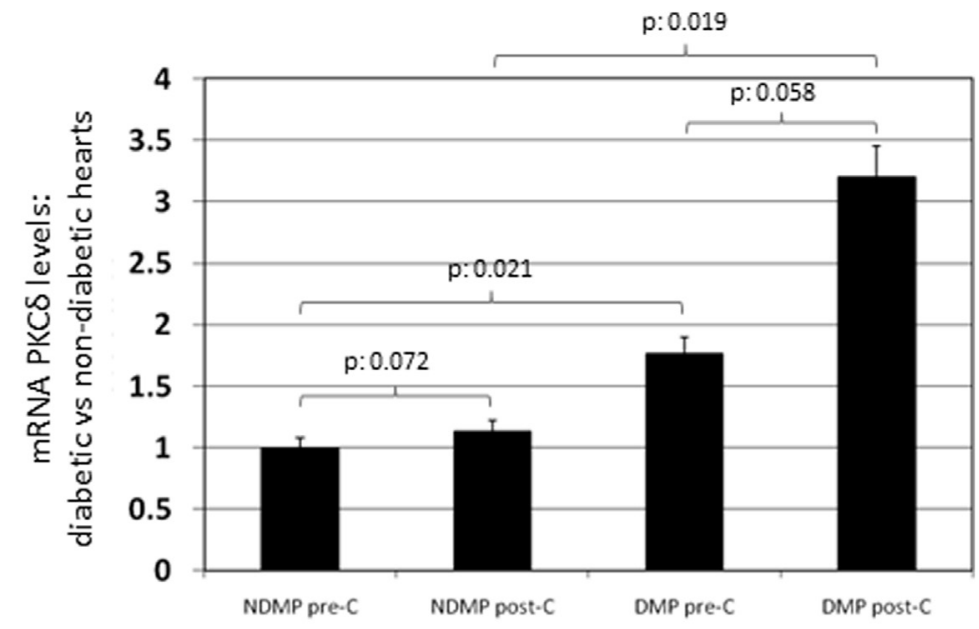

\begin{tabular}{|c|c|c|c|c|}
\hline & \multicolumn{2}{|c|}{ Non-diabetic hearts } & \multicolumn{2}{|c|}{ Diabetic hearts } \\
\hline Total PKC $\delta$ & 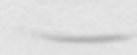 & $\underline{\sim}$ & 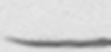 & $\longrightarrow$ \\
\hline \multirow{2}{*}{\multicolumn{5}{|c|}{ Phospho-PKCS }} \\
\hline & & & & \\
\hline & Pre-CP & Post-CP & Pre-CP & Post-CP \\
\hline Total PKC $\delta$ & 1 & 1.1 & 2.4 & 3.7 \\
\hline $\mathrm{p}$ values total PKCS & $\begin{array}{l}0.027 \\
\text { vs DMPP } \\
\text { PreecP }\end{array}$ & $\underset{\substack{0.066 \\
\text { v NDMM } \\
\text { Prece }}}{0.06}$ & \multirow{2}{*}{$\begin{array}{c}0.027 \\
\text { vo NDMP } \\
\text { Prec-CP }\end{array}$} & $\begin{array}{l}0.019 \\
v=0 \mathrm{DMP} \\
\text { Preec }\end{array}$ \\
\hline & & & & $\begin{array}{c}0.0028 \\
v=\text { NDMP } \\
\text { Post-C }\end{array}$ \\
\hline Phospho-PKCठ & 1 & 1.1 & 1.5 & 4.1 \\
\hline $\mathrm{p}$ values $\mathrm{P}-\mathrm{PKC} \delta$ & $\begin{array}{l}0.034 \\
\text { is DMP } \\
\text { Prec-CP }\end{array}$ & 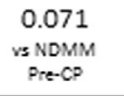 & \multirow{2}{*}{$\begin{array}{c}0.034 \\
\text { va NOMP } \\
\text { PreeCP }\end{array}$} & $\begin{array}{c}0.023 \\
\text { vo DMP } \\
\text { Prec- }\end{array}$ \\
\hline & & & & $\begin{array}{c}0.0035 \\
\text { vo NDMP } \\
\text { Posst-C }\end{array}$ \\
\hline Actin & 1 & 1 & 1 & 1 \\
\hline
\end{tabular}

FIGURE 3. A, Quantitative polymerase chain reaction of protein kinase $\mathrm{C}(P K C) \delta$ urocortin messenger RNA (mRNA) levels from pre- and postcardioplegic $(C P)$ myocardial samples of patients without $(N D M P s)$ and with $(D M P s)$ diabetes mellitus. $* * P<.01$ and $* P<.05$. B, Western blotting of extracts from nondiabetic and diabetic human hearts before and after cardioplegic arrest showing expression of total and phosphorylated PKC $\delta$ protein. A total of 54 samples from DMPs (27 taken before cardioplegia and 27 after release of aortic crossclamping) and 44 samples from NDMPs (22 obtained 
Moreover, both preoperative $\mathrm{e}^{2,34}$ and postoperative ${ }^{35}$ hyperglycemia have been reported as important predictors of late mortality after CABG. A recent report by Voisine and colleagues ${ }^{9}$ clearly showed qualitative and quantitative differences in gene expression profiles from cardiac myocytes of DMPs compared with NDMPs, in particular, those related to the inflammatory response and oxidative stress after CPB with cardioplegic arrest. However, the molecular mechanisms activated in DM after cardioplegic arrest that contribute to the worse periprocedural outcomes for this high-risk cohort of patients remain poorly understood. The molecular mechanisms reported in the present study could contribute to a better understanding and improved management of the response of the DM heart to cardioplegic arrest.

In addition to inducing oxidative stress and negative inotropism in the heart, ${ }^{22}$ hyperglycemia has been found to induce mitochondrial dysfunction, cytochrome-c release, and apoptosis. ${ }^{36}$ Hyperglycemia is a powerful activating signal for cardiac PKC isozymes, which in turn have been associated with modulation of apoptosis. ${ }^{22}$ In primary cultures of serum-starved adult rat ventricular myocytes, hyperglycemia induced apoptotic cell death, which was attenuated by administration of peptide inhibitors of PKC beta-I/beta-2, and zeta, although not PKC $\varepsilon$ (epsilonV1-2). ${ }^{22}$ In contrast, the $\mathrm{PKC} \varepsilon$ translocation activator (psi epsilon RACK) abolished hyperglycemia-induced apoptosis, strongly suggesting a cardioprotective role for PKCe in hyperglycemia-induced apoptosis. ${ }^{36}$

Activation of $\mathrm{PKC} \delta$, another PKC isoform, has been reported in ventricular myocytes under hyperglycemic conditions. ${ }^{22}$ In adult rat ventricular myocytes, treatment with hyperglycemia $(16.5 \mathrm{mM})$ for 24 hours resulted in a greater than threefold increase in apoptosis compared with baseline and in membrane translocation and activation of $\operatorname{PKC} \delta .{ }^{22}$ Hyperglycemia-induced apoptosis was attenuated by the $\mathrm{PKC} \delta$-specific translocation inhibitor peptide (deltaV11). ${ }^{22,32}$ In an isolated perfused rat heart model of $I / R$ injury, the inhibition of $\mathrm{PKC} \delta$ prevented reperfusion injury, and activation of $\mathrm{PKC} \varepsilon$ mimicked ischemic preconditioning, confirming the opposite effects exerted in vitro and ex vivo by $\mathrm{PKC} \delta$ and PKC $\varepsilon$ in the context of I/R injury. ${ }^{36}$

In our study, we have shown for the first time that, in the hearts of DMPs, the baseline cardiomyocyte expression of Ucn, a well-known cardioprotective agent, is roughly one half that in the hearts of NDMPs. Also, in contrast to the NDMP hearts, it was not increased after cardioplegia. The reduced Ucn in the hearts of the DMPs was associated, not only with a reduced baseline expression of PKC $\varepsilon$, which failed to relocate after cardioplegic arrest, but also by overexpression of $\mathrm{PKC} \delta$, whose postcardioplegic translocation to the nuclei was seen in apoptotic myocytes. We previously reported that human hearts exposed to mild forms of surgical ischemia exhibited $\mathrm{PKC} \varepsilon$ phosphorylation and mitochondrial translocation, which promoted cell survival, but only in myocytes expressing Ucn. Thus, a low baseline Ucn level, together with an inability to increase its expression after cardioplegic arrest, can contribute to making diabetic hearts more susceptible to apoptosis, which would, in turn, contribute to adverse postoperative outcomes.

Different volatile anesthetics, including isoflurane, have been shown to provide cardioprotection in patients undergoing $\mathrm{CABG}$ with $\mathrm{CPB} .^{37}$ The mechanism of anesthetic-induced cardioprotection seems to be related to $\mathrm{PKC} \varepsilon$-induced preconditioning by delayed opening of the mitochondrial permeability transition pore. ${ }^{38,39}$ Because all the patients enrolled in our study received the same anesthesia regimen, it is possible that DMPs might benefit to a lesser extent from anesthetic-induced cardioprotection owing to the low preoperative levels and the lack of postoperative induction of PKC $\varepsilon$.

We have previously shown that in the rat heart exposed to I/R injury, Ucn exerts a cytoprotective action that is independent of an energy-sparing mechanism secondary to a negative inotropic effect and is associated with both recovery of cardiac performance and reduced depletion of endogenous high-energy phosphates. ${ }^{40}$ The degree of cardiac dysfunction after I/R injury reflects the level of myocyte injury and death. Cell death after injury, and the form that it takes, is largely dependent on the intracellular adenosine triphosphate (ATP) levels and other high energy phosphates. ${ }^{41}$ For example, viable cells will have an ADP/ATP ratio of $<0.11$, apoptotic cells a ratio of 0.11 to 1.0 , and necrotic cells, a ratio of $\leq 15 .^{42}$ The Ucn-induced recovery of ATP stores, with a reduction of the intracellular ADP/ ATP ratio, might allow damaged myocytes that would otherwise die by necrosis to die by the alternative apoptotic pathway. Because necrosis, unlike apoptosis, is associated with the release of intracellular contents and a subsequent inflammatory reaction, a reduction in the proportion of necrotic death will result in a smaller final lesion, with functional benefit. The greater troponin release and the doubled percentage of apoptotic cell death documented in the DMPs would be consistent with this interpretation. Accordingly, supplementation of cardioplegic solutions with exogenous

before cardioplegia and 22 after release of aortic crossclamping) were processed. To obtain adequate amounts of proteins and mRNA, pre- and postcardioplegic samples collected from 3 different patients were combined and processed together, with exception of 1 pre- and postcardioplegic batch from NDMPs composed of 4 samples. The data shown are representative of 3 different experiments. 
A
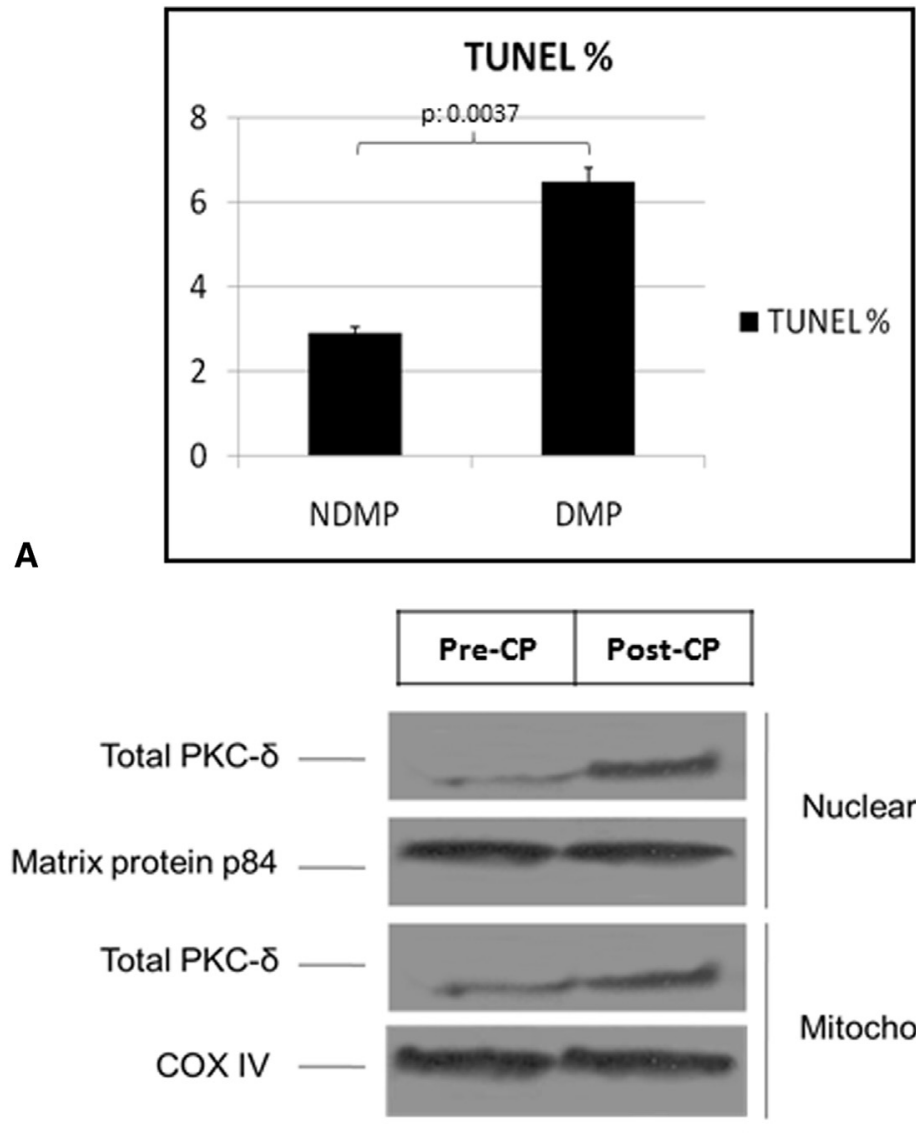

Nuclear fraction

Total PKC- $\delta$

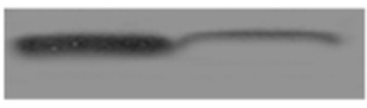

Actin

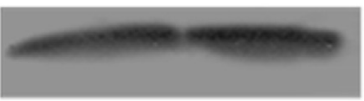

Cytoplasmic fraction

\begin{tabular}{|c|c|c|c|}
\hline & Diabe & hearts & \\
\hline Total PKC- $\delta$ & 1 & 3.4 & \multirow{2}{*}{$\begin{array}{l}\text { Nuclear } \\
\text { fraction }\end{array}$} \\
\hline Matrix protein $\mathrm{p} 84$ & 1 & 1 & \\
\hline Total PKC- $\delta$ & 1 & $2.1^{*}$ & \multirow{2}{*}{$\begin{array}{l}\text { Mitochondrial } \\
\text { fraction }\end{array}$} \\
\hline HSP60 & 1 & 1 & \\
\hline Total PKC- $\delta$ & 1 & $0.2^{* *}$ & \multirow{2}{*}{$\begin{array}{l}\text { Cytoplasmic } \\
\text { fraction }\end{array}$} \\
\hline Actin & 1 & 1 & \\
\hline & Pre-CP & Post-CP & \\
\hline
\end{tabular}

FIGURE 4. A, Occurrence of apoptotic cell death as assessed by terminal deoxynucleotidyl transferase mediated nick end labeling (TUNEL) staining at the end of cardioplegic $(C P)$ arrest in myocardial sections from the hearts of patients without (NDMPs) and with (DMPs) diabetes mellitus. A total of 5 different sections for each collected sample were analyzed. Data are expressed as the mean \pm standard deviation of 12 to 15 high-power fields. B, Nuclear and 
TABLE 3. Percentages of cardiac cells with positive labeling for pPKC $\varepsilon$, pPKC $\delta$, urocortin, and TUNEL in DMPs and NDMPs before and after cardioplegic arrest

\begin{tabular}{|c|c|c|c|c|c|c|c|c|c|c|c|c|}
\hline & \multicolumn{2}{|c|}{$\begin{array}{l}\text { pPKC } \varepsilon \text {-positive } \\
\text { cytosol }\end{array}$} & \multicolumn{2}{|c|}{$\begin{array}{c}\text { pPKC } \delta \text {-positive } \\
\text { cytosol }\end{array}$} & \multicolumn{2}{|c|}{$\begin{array}{c}\text { pPKC } \varepsilon / \text { mitochondria } \\
\text { co-localization }\end{array}$} & \multicolumn{2}{|c|}{$\begin{array}{l}\text { pPKC } \delta / \text { nuclei } \\
\text { co-localization }\end{array}$} & \multicolumn{2}{|c|}{$\begin{array}{c}\text { Urocortin-positive } \\
\text { myocytes }\end{array}$} & \multicolumn{2}{|c|}{ TUNEL } \\
\hline & DMPs & NDMPs & DMPs & NDMPs & DMP & NDMP & DMP & NDMP & DMP & NDMP & DMP & NDMP \\
\hline Before $\mathrm{CP}$ & $2.7 \pm 0.3$ & $7.1 \pm 0.8$ & $6.8 \pm 1.1$ & $1.6 \pm 0.3$ & $0.8 \pm 0.3$ & $2.4 \pm 0.4$ & $0.9 \pm 0.2$ & $<0.1$ & $0.9 \pm 0.3$ & $2.7 \pm 0.5$ & $1.2 \pm 0.4$ & $<0.1$ \\
\hline After CP & $3.4 \pm 0.4$ & $26.7 \pm 3.7$ & $19.3 \pm 2.8$ & $2.2 \pm 0.5$ & $1.4 \pm 0.5$ & $22 \pm 2.8$ & $7.9 \pm 1.8$ & $3.3 \pm 0.5$ & $1.6 \pm 0.5$ & $23 \pm 2.6$ & $6.4 \pm 1.3$ & $2.9 \pm 0.6$ \\
\hline$P$ value** & .039 & .019 & .023 & .069 & .042 & .002 & .009 & .019 & .062 & .003 & .006 & .037 \\
\hline
\end{tabular}

Data presented as mean percentage \pm standard deviation of 12-15 high power fields. Five different sections for each collected sample were analyzed. $p P K C$, Phosphorylated protein kinase C; TUNEL, terminal deoxynucleotidyl transferase mediated nick end labeling; DMPs, patients with diabetes mellitus; NDMPs, patients without diabetes mellitus; $C P$, cardioplegia. *Postcardioplegic specimens versus corresponding precardioplegic samples.

Ucn warrants investigation to enhance the intrinsic cardioprotective mechanisms of the diabetic heart, thus reducing the risk of postoperative cardiac dysfunction in DMPs exposed to the inescapable I/R injury associated with OPCS.

\section{Clinical Inferences}

The main clinical finding of the present study was that despite a similar clinical outcome between the DMPs and NDMPs (documented by the negligible and comparable incidence of perioperative acute myocardial infarction, pneumonia, acute renal insufficiency, and the need for prolonged intubation), DMPs had greater perioperative troponin I leakage and suboptimal echocardiographic results. It is well known that perioperative troponin I leakage reflects the quality of myocardial protection and that its value has prognostic implications for mid- to long-term follow-up. ${ }^{43,44}$ Furthermore, variable degrees of myocardial damage with systolic dysfunction will occur even after successful myocardial revascularization because of iatrogenic myocardial I/R injury. ${ }^{9,43,45}$ Accordingly, suboptimal myocardial protection strategies, as shown by the molecular results reported in the present study and further documented by the perioperative troponin I leakage, might help to understand the worse prognosis of DMPs compared with NDMPs reported in published studies. ${ }^{1,5-8}$ The greater perioperative troponin leakage also helps to understand why the DMPs did not show any postoperative recovery in the WMSI and LV ejection fraction, ${ }^{43,44}$ the opposite of that seen in the NDMPs.

It has recently been demonstrated that DMPs have greater post-CABG diastolic dysfunction compared with NDMPs ${ }^{46}$ with a linear correlation between the duration of DM, ${ }^{47}$ and that both diastolic ${ }^{46,48}$ and systolic ${ }^{49}$ dysfunction after $\mathrm{CABG}$ significantly impair outcome. Moreover, contradictory results for $\mathrm{LV}$ diastolic function after CABG have been reported. Hedman and colleagues ${ }^{28}$ showed early improvement of diastole after CABG. However, Diller and colleagues $^{50}$ demonstrated early improvement followed by a late decline of LV relaxation that had reached the preoperative values within 18 months postoperatively. Other investigators have found CPB-related early impairment of LV relaxation. ${ }^{51}$ Our data could help to clarify these contradictory results, because myocardial relaxation during diastole is an energy-dependent process requiring an effective oxygen supply ${ }^{28}$; therefore, less adequate techniques of myocardial protection or a less effective ability to resist ischemia and ischemia-reperfusion during the crossclamp time or at reperfusion, respectively, could induce myocardial contracture. ${ }^{52,53}$ Thus, it could be expected that myocardial tissues unable to adequately counteract ischemia and I/R injury, such as the myocardial cells of DMPs, would show impaired postoperative relaxation, resulting in LV diastolic dysfunction. Thus, the absence of any postoperative recovery from the preoperative diastolic dysfunction seen in our series of DMPs can be considered the net result between the beneficial effects of myocardial revascularization and the deleterious effects of preoperative ischemia and intraoperative $I / R$ injury, together with a "less adequate" strategy of myocardial protection during the crossclamp time (ie, a less adequate capacity to counteract the unavoidable intraoperative $I / R$ injury). Therefore, given the comparable preoperative status and the similar successful myocardial revascularization in both groups, the worse diastolic function of the DMPs can be ascribed to a worse ability of the myocardial cells to withstand I/R injury. More studies are mandatory to better understand the clinical effect of these molecular mechanisms. However, the results from the present study have confirmed the urgent need for improved myocardial protection strategies for DMPs referred for CABG, given the profound effect on outcome of high troponin leakage ${ }^{43,44}$ and any decline in postoperative systolic and/or diastolic function. ${ }^{47-49}$ The increasing knowledge of the molecular mechanisms

\footnotetext{
mitochondrial translocation of protein kinase $\mathrm{C}(P K C) \delta$ in the human heart exposed to CP arrest as assessed by Western blotting in protein extracts from cardiac samples of NDMPs and DMPs collected before and after CP. Matrix protein p84, cytochrome oxidase subunit IV (COX IV), and actin were used as specific markers of the nuclear, mitochondrial, and cytosolic fractions, respectively.
} 

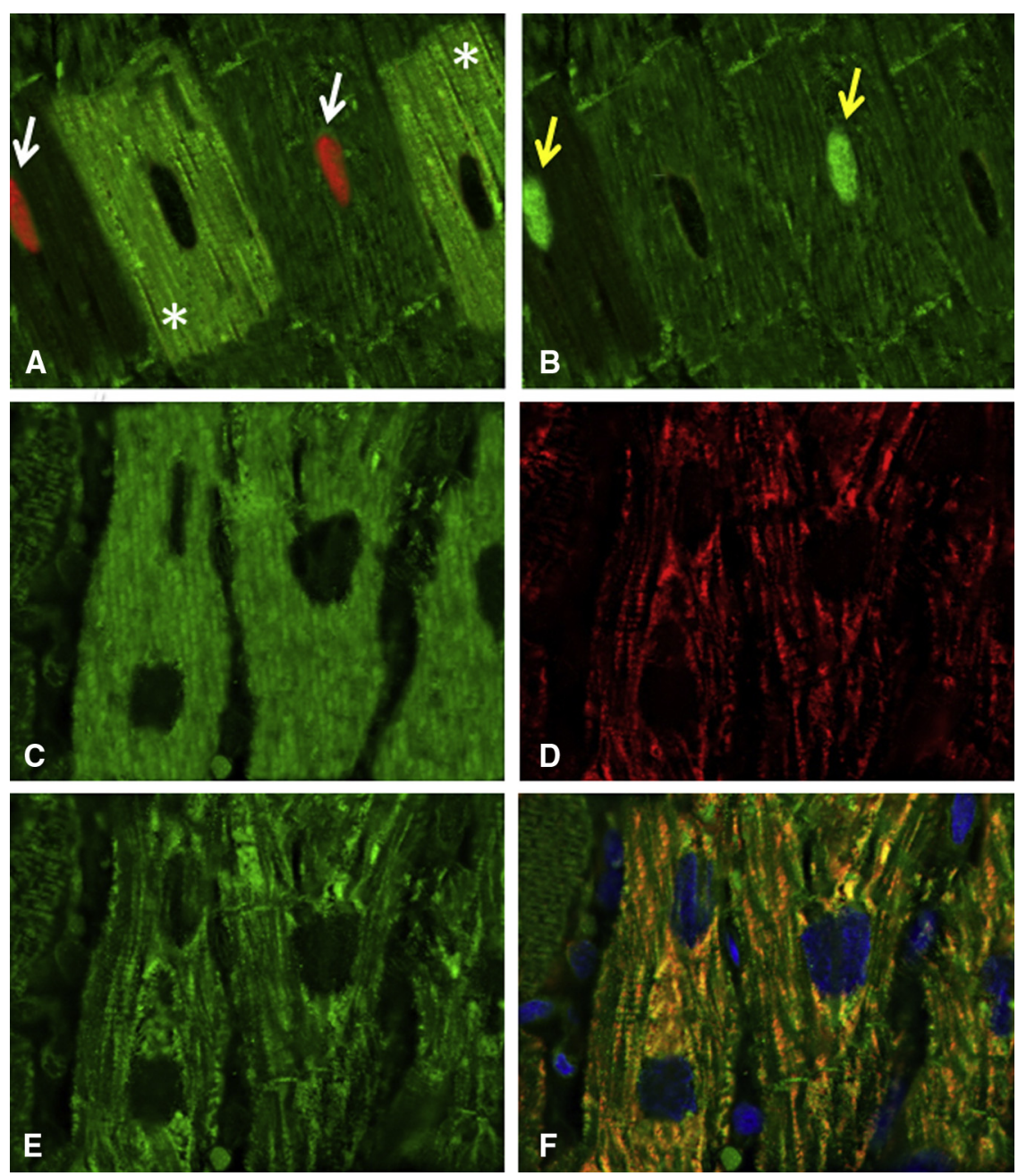

FIGURE 5. Two adjacent 5- $\mu \mathrm{m}$ myocardial sections serially cut from the same postcardioplegic wax block of a patient with diabetes. The sections were stained with (A) an antibody against urocortin (white asterisk) and rhodamine-based terminal deoxynucleotidyl transferase mediated nick end labeling (TUNEL) reagents (white arrow) or (B) an antibody against phosphorylated protein kinase C (PKC) $\delta$ (yellow arrow). Secondary antibodies conjugated with fluorescein were used to label the primary antibody against urocortin (A, bright green cytosol) and phosphorylated $\mathrm{PKC} \delta$ (B, bright green nuclei). A, Urocortin-negative cells were TUNEL negative, but, (B) adjacent urocortin-negative cells with apoptotic nuclei stained red by TUNEL reagents also exhibited nuclear translocation of PKC $\delta$. A total of 54 samples from diabetic patients ( 27 taken before cardioplegia and 27 after release of aortic crossclamping) and 44 samples from nondiabetic patients (22 obtained before cardioplegia and 22 after release of aortic crossclamping) were processed. Five different sections for each collected sample were analyzed. A and B, The images depicted were representative of 27 myocardial samples harvested from diabetic patients after cardioplegic arrest. Data are expressed as the mean \pm standard deviation of 12 to 15 high-power fields. Myocardial sections from atrial tissues collected from a nondiabetic patient after cardioplegic arrest. C, The first section was stained with primary antibody against urocortin and a secondary antibody conjugated with fluorescein. Positive cells appear bright green. D, The second section was stained with 2 different primary antibodies (anti-cytochrome oxidase subunit IV [COX IV], a specific mitochondrial marker, and anti-phosphorylated PKCE) and finally counterstained with the nuclear marker TOPRO-3 (blue staining). COX IV stained bright red by a secondary antibody conjugated with rhodamine. E, PKC $\varepsilon$ stained bright green by a secondary antibody conjugated with fluorescein. F, An overlay of the 3 stains is shown. The percentage of co-localization of phosphorylated PKC $\varepsilon$ and mitochondria was digitally quantified using image analyzer software. D, Visually, an overlap of "green" phosphorylated PKC $\varepsilon$ and "red" mitochondria resulted in a bright orange fluorescent signal that could be observed in the merged images. Five different sections for each collected sample were analyzed. C-F, Representative images of 22 myocardial samples harvested from nondiabetic patients after cardioplegic arrest. Data are expressed as the mean \pm standard deviation of 12 to 15 high-power fields.

underlying perioperative systolic and diastolic dysfunction in DMPs undergoing CABG, and the potential beneficial effects of Ucn, possibly incorporated into cardioplegic solutions, on the intracellular pathways modulating post-CABG myocardial cell survival and apoptosis could positively affect the post-CABG outcome of DMPs. 
TABLE 4. Association of PKC $\varepsilon$ mitochondrial relocation and $\mathrm{PKC} \delta$ nuclear relocation with urocortin and TUNEL staining in myocardial samples after cardioplegic arrest

\begin{tabular}{|c|c|c|c|c|}
\hline \multirow[b]{2}{*}{ Myocytes } & \multicolumn{2}{|c|}{ Post-CP pPKC $\varepsilon /$ mitochondria co-localization } & \multicolumn{2}{|c|}{ Post-CP pPKC $\delta /$ nuclei co-localization } \\
\hline & DMPs & NDMPs & DMPs & NDMPs \\
\hline Overall co-localization & $1.4 \pm 0.5 ; P=.048$ & $22 \pm 2.8 ; P=.0001$ & $7.9 \pm 1.8 ; P=.016$ & $3.3 \pm 0.5 ; P=.042$ \\
\hline \multicolumn{5}{|l|}{ Urocortin } \\
\hline Positive & $1.1 \pm 0.3 ; P=.00033$ & $18 \pm 2.1 ; P=.00028$ & $<0.1 ; P=<.00001$ & $<0.1 ; P=<.00001$ \\
\hline Negative & $0.3 \pm 0.2 ; P=.00018$ & $4 \pm 0.6 ; P=.00027$ & $7.9 \pm 1.8 ; P=<.00001$ & $3.3 \pm 0.5 ; P=<.00001$ \\
\hline \multicolumn{5}{|l|}{ TUNEL } \\
\hline Negative & $1.4 \pm 0.5 ; P=1$ & $22 \pm 2.8 ; P=1$ & $1.5 \pm 0.4 ; P=.048$ & $0.4 \pm 0.2 ; P=.0023$ \\
\hline Positive & $<0.1 ; P<.00001$ & $<0.1 ; P<.00001$ & $6.4 \pm 1.3 ; P=.0023$ & $2.9 \pm 0.6 ; P=.0041$ \\
\hline
\end{tabular}

$T U N E L$, terminal deoxynucleotidyl transferase mediated nick end labeling; $C P$, cardioplegia; $D M P s$, patients with diabetes mellitus; NDMPs, patients without diabetes mellitus.

\section{Study Limitations}

One potential limitation of our study was the use of atrial rather than ventricular specimens. However, the choice of atrial tissue was dictated by ethical constraints, because atrial, unlike ventricular, biopsy carries no significant morbidity and provides full-thickness samples that are readily reproducible. Although the atrial myocardium differs from the ventricular myocardium with respect to the relative percentage of myocyte, endothelial, connective, and neural elements, all these cell types are also present in ventricular tissue and demonstrate similar ultrastructural changes in human heart disease. ${ }^{9}$ It has also been shown that the gene profiles show similar patterns of expression in both ventricular and atrial tissue before and after cardioplegic arrest. $^{9}$

Finally, the present study was not intended for clinical purposes; therefore, the related clinical results must be considered as descriptive only (our study was underpowered to detect differences in the major clinical outcome variables).

We wish to thank the St John Guild Foundation and the Medical Education Department of St John Hospital and Medical Center for the continuous and most generous financial support.

\section{References}

1. Carson JL, Scholz PM, Chen AY, Peterson ED, Gold J, Schneider SH. Diabetes mellitus increases short-term mortality and morbidity in patients undergoing coronary artery bypass graft surgery. J Am Coll Cardiol. 2002;40:418-23.

2. Lawrie GM, Morris GC Jr, Glaeser DH. Influence of diabetes mellitus on the results of coronary bypass surgery: follow-up of 212 diabetic patients ten to 15 years after surgery. JAMA. 1986;256:2967-71.

3. Morris JJ, Smith LR, Jones RH, Glower DD, Morris PB, Muhlbaier LH, et al. Influence of diabetes and mammary artery grafting on survival after coronary bypass. Circulation. 1991;84:III275-84.

4. Risum O, Abdelnoor M, Svennevig JL, Levorstad K, Gullestad L, Bjornerheim R, et al. Diabetes mellitus and morbidity and mortality risks after coronary artery bypass surgery. Scand J Thorac Cardiovasc Surg. 1996;30: $71-5$.

5. Barsness GW, Peterson ED, Ohman EM, Nelson CL, DeLong ER, Reves JG, et al. Relationship between diabetes mellitus and long-term survival after coronary bypass and angioplasty. Circulation. 1997;96:2551-6.

6. Herlitz J, Wognsen GB, Emanuelsson H, Haglid M, Karlson BW, Karlsson T, et al. Mortality and morbidity in diabetic and nondiabetic patients during a 2- year period after coronary artery bypass grafting. Diabetes Care. 1996;19: 698-703.

7. Salomon NW, Page US, Okies JE, Stephens J, Krause AH, Bigelow JC. Diabetes mellitus and coronary artery bypass: short-term risk and long-term prognosis. $J$ Thorac Cardiovasc Surg. 1983;85:264-71.

8. Thourani VH, Weintraub WS, Stein B, Gebhart SS, Craver JM, Jones EL, et al. Influence of diabetes mellitus on early and late outcome after coronary artery bypass grafting. Ann Thorac Surg. 1999;67:1045-52.

9. Voisine P, Ruel M, Khan TA, Bianchi C, Xu SH, Kohane I, et al. Differences in gene expression profiles of diabetic and nondiabetic patients undergoing cardiopulmonary bypass and cardioplegic arrest. Circulation. 2004;110:II280-6.

10. Hakala T, Pitkanen O, Halonen P, Mustonen J, Turpeinen A, Hippelainen M Early and late outcome after coronary artery bypass surgery in diabetic patients. Scand Cardiovasc J. 2005;39:177-81.

11. Woods SE, Smith JM, Sohail S, Sarah A, Engle A. The influence of type 2 diabetes mellitus in patients undergoing coronary artery bypass graft surgery: an 8 year prospective cohort study. Chest. 2004;126:1789-95.

12. Shalaby A, Rinne T, Jarvinen O, Saraste A, Laurikka J, Porkkala H, et al. Initial results of a clinical study: adenosine enhanced cardioprotection and its effect on cardiomyocytes apoptosis during coronary artery bypass grafting. Eur J Cardiothorac Surg. 2008;33:639-44.

13. Scarabelli TM, Pasini E, Ferrari G, Ferrari M, Stephanou A, Lawrence K, et al Warm blood cardioplegic arrest induces mitochondrial-mediated cardiomyocyte apoptosis associated with increased urocortin expression in viable cells. J Thorac Cardiovasc Surg. 2004;128:364-71.

14. Feng J, Liu Y, Dobrilovic N, Chu LM, Bianchi C, Singh AK, et al. Altered apoptosis-related signaling after cardioplegic arrest in patients with uncontrolled type 2 diabetes mellitus. Circulation. 2013;128:S144-51.

15. Vaughan J, Donaldson C, Bittencourt J, Perrin MH, Lewis K, Sutton S, et al. Urocortin, a mammalian neuropeptide related to fish urotensin I and to corticotropin-releasing factor. Nature. 1995;378:287-92.

16. Nishikimi T, Miyata A, Horio T, Yoshihara F, Nagaya N, Takishita S, et al. Urocortin, a member of the corticotropin-releasing factor family, in normal and diseased heart. Am J Physiol Heart Circ Physiol. 2000;279:H3031-9.

17. Brar BK, Stephanou A, Okosi A, Lawrence KM, Knight RA, Marber MS, et al. CRH-like peptides protect cardiac myocytes from lethal ischaemic injury. Mol Cell Endocrinol. 1999;158:55-63.

18. Phrommintikul A, Sivasinprasasn S, Lailerd N, Chattipakorn S, Kuanprasert S, Chattipakorn N. Plasma urocortin in acute myocardial infarction patients. Eur J Clin Invest. 2010;40:874-82.

19. Lawrence KM, Kabir AM, Bellahcene M, Davidson S, Cao XB, McCormick J, et al. Cardioprotection mediated by urocortin is dependent on PKC epsilon activation. FASEB J. 2005;19:831-3.

20. Chen-Scarabelli C, Faggian G, Yuan Z, Tessari M, Rungatscher A, Di Rezze J, et al. Warm-blood cardioplegic arrest induces selective mitochondrial translocation of protein kinase $\mathrm{C}$ epsilon followed by interaction with 6.1 inwardly rectifying potassium channel subunit in viable myocytes overexpressing urocortin. $J$ Thorac Cardiovasc Surg. 2009;138:1213-21.

21. Duquesnes N, Lezoualc'h F, Crozatier B. PKC-delta and PKC-epsilon: foes of the same family or strangers? J Mol Cell Cardiol. 2011;51:665-73.

22. Shizukuda Y, Reyland ME, Buttrick PM. Protein kinase C-delta modulates apoptosis induced by hyperglycemia in adult ventricular myocytes. Am J Physiol Heart Circ Physiol. 2002;282:H1625-34. 
23. Luciani GB, Faggian G, Montalbano G, Casali G, Forni A, Chiominto B, et al. Blood versus crystalloid cardioplegia for myocardial protection of donor hearts during transplantation: a prospective, randomized clinical trial. J Thorac Cardiovasc Surg. 1999;118:787-95.

24. Schagger H. Tricine-SDS-PAGE. Nat Protoc. 2006;1:16-22.

25. Scarabelli TM, Stephanou A, Pasini E, Gitti G, Townsend P, Lawrence K, et al. Minocycline inhibits caspase activation and reactivation, increases the ratio of $\mathrm{XIAP}$ to smac/DIABLO, and reduces the mitochondrial leakage of cytochrome C and smac/DiABLO. J Am Coll Cardiol. 2004;43:865-74.

26. Scarabelli T, Stephanou A, Rayment N, Pasini E, Comini L, Curello S, et al Apoptosis of endothelial cells precedes myocyte cell apoptosis in ischemia/ reperfusion injury. Circulation. 2001;104:253-6.

27. Lang RM, Bierig M, Devereux RB, Flachskampf FA, Foster E, Pellikka PA, et al. Recommendations for chamber quantification: a report from the American Society of Echocardiography's Guidelines and Standards Committee and the Chamber Quantification Writing Group, developed in conjunction with the European Association of Echocardiography, a branch of the European Society of Cardiology. J Am Soc Echocardiogr. 2005;18:1440-63.

28. Hedman A, Samad BA, Larsson T, Zuber E, Nordlander R, Alam M. Improvement in diastolic left ventricular function after coronary artery bypass grafting as assessed by recordings of mitral annular velocity using Doppler tissue imaging. Eur J Echocardiogr. 2005;6:202-9.

29. Szekely A, Levin J, Miao Y, Tudor IC, Vuylsteke A, Ofner P, et al. Impact of hyperglycemia on perioperative mortality after coronary artery bypass graft surgery. J Thorac Cardiovasc Surg. 2011;142:430-7.e1.

30. Doenst T, Wijeysundera D, Karkouti K, Zechner C, Maganti M, Rao V, et al. Hyperglycemia during cardiopulmonary bypass is an independent risk factor for mortality in patients undergoing cardiac surgery. J Thorac Cardiovasc Surg. 2005;130:1144.

31. D'Alessandro C, Leprince P, Golmard JL, Ouattara A, Aubert S, Pavie A, et al. Strict glycemic control reduces EuroSCORE expected mortality in diabetic patients undergoing myocardial revascularization. J Thorac Cardiovasc Surg. 2007; 134:29-37.

32. Furnary AP, Gao G, Grunkemeier GL, Wu Y, Zerr KJ, Bookin SO, et al. Continuous insulin infusion reduces mortality in patients with diabetes undergoing coronary artery bypass grafting. J Thorac Cardiovasc Surg. 2003;125:1007-21.

33. Jessen ME. Glucose control during cardiac surgery: how sweet it is. J Thorac Cardiovasc Surg. 2003;125:985-7.

34. Anderson RE, Klerdal K, Ivert T, Hammar N, Barr G, Owall A. Are even impaired fasting blood glucose levels preoperatively associated with increased mortality after CABG surgery? Eur Heart J. 2005;26:1513-8.

35. Jones KW, Cain AS, Mitchell JH, Millar RC, Rimmasch HL, French TK, et al. Hyperglycemia predicts mortality after $\mathrm{CABG}$ : postoperative hyperglycemia predicts dramatic increases in mortality after coronary artery bypass graft surgery. J Diabetes Complications. 2008;22:365-70.

36. Inagaki K, Hahn HS, Dorn GW II, Mochly-Rosen D. Additive protection of the ischemic heart ex vivo by combined treatment with delta-protein kinase $\mathrm{C}$ inhibitor and epsilon-protein kinase C activator. Circulation. 2003;108:869-75.

37. Tritapepe L, Landoni G, Guarracino F, Pompei F, Crivellari M, Maselli D, et al. Cardiac protection by volatile anaesthetics: a multicentre randomized controlled study in patients undergoing coronary artery bypass grafting with cardiopulmonary bypass. Eur J Anaesthesiol. 2007;24:323-31.

38. Aizawa K, Turner LA, Weihrauch D, Bosnjak ZJ, Kwok WM. Protein kinase C-epsilon primes the cardiac sarcolemmal adenosine triphosphate- sensitive potassium channel to modulation by isoflurane. Anesthesiology. 2004; 101:381-9.

39. Pravdic D, Sedlic F, Mio Y, Vladic N, Bienengraeber M, Bosnjak ZJ. Anestheticinduced preconditioning delays opening of mitochondrial permeability transition pore via protein kinase C-epsilon-mediated pathway. Anesthesiology. 2009;111: 267-74.

40. Scarabelli TM, Pasini E, Stephanou A, Comini L, Curello S, Raddino R, et al. Urocortin promotes hemodynamic and bioenergetic recovery and improves cell survival in the isolated rat heart exposed to ischemia/reperfusion. J Am Coll Cardiol. 2002;40:155-61.

41. Leist M, Single B, Castoldi AF, Kuhnle S, Nicotera P. Intracellular adenosine triphosphate (ATP) concentration: a switch in the decision between apoptosis and necrosis. J Exper Med. 1997;185:1481-6.

42. Bradbury DA, Simmons TD, Slater KJ, Crouch SP. Measurement of the ADP: ATP ratio in human leukaemic cell lines can be used as an indicator of cell viability, necrosis and apoptosis. J Immunol Methods. 2000;240:79-92.

43. Onorati F, De Feo M, Mastroroberto P, Cristodoro L, Pezzo F, Renzulli A, et al. Determinants and prognosis of myocardial damage after coronary artery bypass grafting. Ann Thorac Surg. 2005;79:837-45.

44. Muehlschlegel JD, Perry TE, Liu KY, Nascimben L, Fox AA, Collard CD, et al. Troponin is superior to electrocardiogram and creatinine kinase MB for predicting clinically significant myocardial injury after coronary artery bypass grafting. Eur Heart J. 2009;30:1574-83.

45. Onorati F, Santini F, Dandale R, Ucci G, Pechlivanidis K, Menon T, et al. "Polarizing" microplegia improves cardiac cycle efficiency after CABG for unstable angina. Int J Cardiol. 2013;167:2739-46.

46. Wu YW, Hsu CL, Wang SS, Tsai MW, Chu SH, Chen YS, et al. Impaired exercise capacity in diabetic patients after coronary bypass surgery: effects of diastolic and endothelial function. Cardiology. 2008;110:191-8.

47. Mishra TK, Rath PK, Mohanty NK, Mishra SK. Left ventricular systolic and diastolic dysfunction and their relationship with microvascular complications in normotensive, asymptomatic patients with type 2 diabetes mellitus. Ind Heart J. 2008;60:548-53.

48. Sastry P, Theologou T, Field M, Shaw M, Pullan DM, Fabri BM. Predictive accuracy of EuroSCORE: is end-diastolic dysfunction a missing variable? Eur J Cardiothorac Surg. 2010;37:261-6.

49. Kosmala W, Spring A, Witkowska M. [Relationship between systolic and diastolic function of the left ventricle in patients with impaired relaxation of the left ventricle without symptoms of heart failure: attempt at quantitative estimation of diastolic function in the impaired relaxation stage]. Pol Arch Med Wewn. 1997;98:414-23.

50. Diller GP, Wasan BS, Kyriacou A, Patel N, Casula RP, Athanasiou T, et al. Effect of coronary artery bypass surgery on myocardial function as assessed by tissue Doppler echocardiography. Eur J Cardiothorac Surg. 2008;34: 995-9.

51. McKenney PA, Apstein CS, Mendes LA, Connelly GP, Aldea GS, Shemin RJ, et al. Increased left ventricular diastolic chamber stiffness immediately after coronary artery bypass surgery. J Am Coll Cardiol. 1994;24:1189-94.

52. Rudd DM, Dobson GP. Eight hours of cold static storage with adenosine and lidocaine (Adenocaine) heart preservation solutions: toward therapeutic suspended animation. J Thorac Cardiovasc Surg. 2011;142:1552-61.

53. Rudd DM, Dobson GP. Early reperfusion with warm, polarizing adenosinelidocaine cardioplegia improves functional recovery after 6 hours of cold static storage. J Thorac Cardiovasc Surg. 2011;141:1044-55. 